\title{
Identifikasi Kesegaran Ikan Berdasarkan Citra Insang Dengan Metode Convolution Neural Network
}

\author{
Miftahus Sholihin*¹, M. Rosidi Zamroni ${ }^{2}$, Burhanuddin ${ }^{3}$ \\ ${ }^{1,2}$ Universitas Islam Lamongan; Jl. Veteran No. 53 A Lamongan \\ ${ }^{3}$ Jurusan Teknik Informatika, Fakultas Teknik Unisla, Lamongan \\ e-mail: ${ }^{* 1}$ miftahus.sholihin@ unisla.ac.id, ${ }^{2}$ rosidizamroni@ gmail.com, \\ ${ }^{3}$ kabur.burhan@gmail.com
}

\begin{abstract}
Abstrak
Penelitian ini bertujuan untuk membuat sistem identifikasi kesegaran ikan yang didasarkan pada citra insang ikan. Dengan adanya sistem ini diharapkan masyaratak akan semakin mudah dalam menentukan ikan segar. Metode yang digunakan pada penelitian ini adalah CNN. Data yang digunakan pada penelitian ini berjumlah 150 data citra insang ikan yang dikategorikan kedalam tigas kelas yaitu kelas ikan segar, tidak segar, dan busuk. Penelitian iini memberikan hasil akurasi 100\% untuk proses training dan 97,7\% untuk proses testing.
\end{abstract}

Kata kunci-identifikasi, ikan, CNN, training, testing.

\section{Abstract}

This study aims to create a fish freshness identification system based on the image of fish gills. With this system, it is hoped that the community will find it easier to determine fresh fish. The method used in this study is CNN. The data used in this study amounted to 150 fish gill image data which were categorized into three classes, namely fresh, not fresh, and rotten fish classes. This research provides $100 \%$ accuracy for the training process and $97.7 \%$ for the testing process.

Keywords - identification, fish, CNN, training, testing.

\section{PENDAHULUAN}

Ikan mengandung banyak nutrisi, protein tinggi yang memiliki manfaat bagi tubuh manusia, disamping itu ikan juga memiliki kandungan air yang tinggi [1], sehingga ikan akan mudah mengalami kerusakan/kebusukan. Kualitas ikan yang menurun bisa dilihat dari kulit ikan yang mengalami perubahan warna, mata, tekstur dari daging ikan, dan insang ikan [2]. Sebelum mengkonsumsi ikan, biyasanya konsumen terlebih dahulu akan memilih ikan yang memiliki tingkat kesegaran yang baik atau ikan dalam kondisi segar. Pada umumnya proses penentuan tingkat kesegaran ikan yang dilakukan oleh konsumen masih dilakukan secara manual, analisis mikrobiologi dan kimiawi [3], [4].

Beberapa penelitian terkait dengan identifikasi kesegaran ikan telah banyak dilakukan. Tahun 2016 [2] melakukan penelitian untuk menentukan kesegaran ikan yang didasarkan pada mata ikan. Metode kuadrat terkecil digunakan untuk menentukan kesegaran ikan dengan akurasi 83,3\%. Iswari [5] melakukan penelitian untuk klasifikasi tingkat kesegaran ikan dengan melakukan perbandingan antara metode K-Nearest Neighbor, Naive Bayes, dan C4.5. K- 
Nearest Neighbor menunjukan hasi yang lebih baik. Winiarti [6] melakukan penelitian tentang klasifikasi kesegaran ikan nila dan tenggiri berdasarkan daging ikan yang layak dikonsumsi. Penelitian ini menggunakan metode ciri warna dan ciri tekstur untuk proses ekstraksi ciri, sedangkan klasifikasi menggunakan metode KNN. Akurasi untuk ikan nila sebesar 90\%, sedangakan untuk ikan tengiri sebesar 97,5\%. Agustyawan [7] membedakan kesegaran ikan dengan convolution neural network $(\mathrm{CNN})$ berdasarkan citra mata. Penelitian ini memberikan akurasi sebesar $100 \%$ untuk proses training dan testing. Hutagalung [8] melakukan identifikasi kesegaran ikan nila berdasarkan citra mata kedalam 4 kelas yaitu sangat segar, segar, cukup segar, dan tidak segar. Penelitian ini memberikan akurasi yang sangat bagus, meskipun membutuhkan waktu komputasi yang lama. Khansa [9] mengunakan metode ekstraksi ciri transformasi wavelelet untuk klasifikasi kesegaran ikan berdasarkan tubuh ikan. Rata-rata akurasi pada penelitian ini ketika mengunakan cross validation sebesar 87,66\%, sedangkan ketika tidak menggunakan cross validation akurasi didapatkan $80 \%$. Fitriyah [10] melakukan deteksi kesegran ikan tongkol berdasarkan mata ikan. Penelitian ini menggunakan dua template, yaitu template mata untuk deteksi mata dan template tengah untuk mendeteksi bulatan hitam pada mata ikan. Hasil akhir dari penelitian ini sistem yang dibangun mampu membedakan ikan yang segar dengan tepat. Ekojono [11] melakukan identifikasi kesegaran ikan berdasarkan warna HSV dan morphologi dengan menggunakan insang dan mata ikan. Pada penelitian ini memberikan akurasi tertinggi sebesar 90\% udengan metode HSV dan 85\% dengan menggunakan tekstur.

Berdasarkan beberapa penelitian yang sudah ada, peneliti belum menemukan penelitian tentang identifikasi kesegaran ikan berdasarkan insang ikan dengan menggunakan metode CNN. Metode CNN digunakan karena memiliki tingkat akurasi yang tinggi seperti penelitian yang dilakukan dalam pengenalan citra, hal ini disebabkan karena CNN menirukan sistem pengenalan citra yang dilakukan oleh manusia [12]-[19]. Pada penelitian untuk menentukan kesegaran ikan dibagi kedalam tiga kelas yaitu, segar, tidak segar, dan busuk. Masing-masing kelas terdiri dari 50 data citra insan ikan, sehingga total citra yang digunakan pada penelitian ini berjumlah 150. Pada penelitian ini sistem yang dibangun terdiri dari dua proses utama yaitu proses pelatihan dan proses pengujian. Total data yang dipakai pada penelitian ini adalah 150 terdiri dari 50 citra insang ikan segar, 50 citra insang ikan tidak segar, dan 50 citra insang citra busuk. Dengan adanya sistem ini masyarakn dengan mudah mampu menentukan dalam memilih ikan segar yang akan dikonsumsi.

\section{METODE PENELITIAN}

Gambar 1 adalah langkah-langkah yang dilakukan pada penelitian ini. Tahapan yang pertama adalah identifikasi masalah tahapan ini bertujuan untuk menggali masalah yang akan dipecahkan pada penelitan ini. Tahapan berikutnya adalah studi literature dengan mencari referensi terkait dengan topik yang relevan dengan penelitian, baik dari artikel ilmiah maupun dari buku, dan juga dari sumber-sumber yang lainnya. Tahapan berikutnya adalah pengumpulan data, dimana data yang digunakan pada penelitian ini adalah data citra insang ikan tombro yang diambil langsung dari tempat budidaya ikan tombro. Tahapan selanjutnya adalah perancangan sistem. Setelah perancangan system selesai tahapan selanjutnya adalah implementasi. Implementasi dalam penelitian ini menggunkan bahasa python dengan library opencv dan juga freamwork flask untuk interfacenya. Tahapan yang paling akhir adalah melakukan uji coba terhadap implementasi dari system yang dibuat. Proses implementasi terbagi menjadi dua tahapan yaitu untuk proses training dan proses testing.

Miftahus, et., al [Identifikasi Kesegaran Ikan Berdasarkan Citra Insang Dengan Metode Convolution Neural Network] 


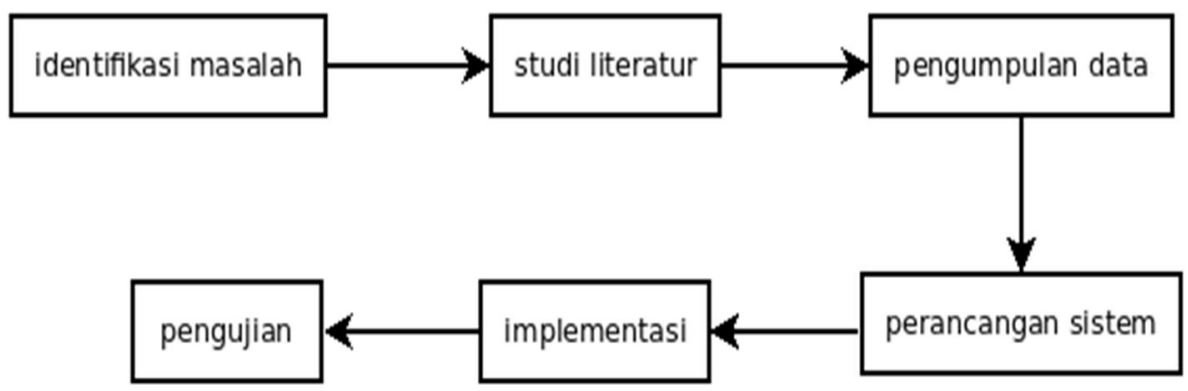

Gambar 1. Tahapan Dalam penelitian

\subsection{Kesegaran Ikan}

Ikan segar adalah ikan yang kondisinya masih sama dengan ikan yang baru saja ditangkap. Ikan segar juga bisa diartikan sebagai ikan yang belum mengalami perubahan apapun [20]. Dilihat dari tingkat kesegaran ikan. Ikan meliliki 4 mutu yaitu mutu baik sekali (prima), mutu baik, mutu sedang, dan mutu tidak segar atau busuk [21].

\section{2 Convolution Neural Network (CNN)}

CNN merupakan kategori dari jaringan saraf yang dirancang untuk pengenalan dan klasifikasi citra dan memberikan hasil yang sangat baik [22]-[25]. CNN digunakan untuk klasifikasi data yang sudah ada labelnya. Metode yang ada pada CNN adalah pembelajaran supervised. Algoritma ini memiliki tujuan untuk menggelompokkan data berdasarkan data yang sudah ada.. Arsitektur CNN yang khas terdiri dari convolution layers, pooling layers, dan full connection layers [26].

\section{2.1 Convolution Layers}

Convolution layer adalah komponen yang sangat penting dari CNN, yang mengekstrak fitur dari sebuah citra dengan ukuran konvolusi kernel yang berbeda-beda. Satu set fitur map dari citra masukan dapat diekstrak setelah menerapkan konvolusi beberapa kali [25]. Tujuan dari konvolusi adalah untuk mengekstrak citra masukan.

\section{2.2 Pooling Layers}

Pada umumnya letak pooling layer setelah convolution layer. Fungsi pooling layer adalah untuk mereduksi sample (downsampling), mempercepat komputasi, dan mengatasi masalah overfitting. Terdapat dua jenis pooling layer yang biasa digunakan yaitu max pooling dan average pooling. Max pooling akan mencari nilai maksimum pada area-area tertentu, sedangkan average pooling mencari fitur pada area tertentu dengan cara mencari nilai rataratanya [27].

\subsubsection{Full Connection Layers}

Setelah convolution dan pooling layers, ada satu atau lebih lapisan full connected (FC) layers. FC adalah lapisan dimana semua neuron aktivasi dari lapisan sebelumnya terhubung dengan neuron di lapisan selanjutnya. Tujuan dari FC adalah untuk melakukan klasifikasi citra berdasarkan citra yang sudah diekstraksi fiturnya. 


\section{HASIL DAN PEMBAHASAN}

Pada bagian ini akan dijelaskan mengenai data yang digunakan dalam uji coba beserta hasil yang didapatkan.

\subsection{Data Citra}

Penelitian ini menggunakan data insang ikan tombro. Penelitan ini menggunakan 150 data insang citra ikan tombro yang dibagi menjadi 105 untuk proses training dan 45 untuk proses testing. Data citra ikan tombro diambil secara langsung dari tempat budidaya ikan tombro. Jarak pengambilan citra insang ikan tombro adalah $50 \mathrm{~cm}$.

\subsection{Pembuatan Model Jaringan}

Gambar 2 adalah model jaringan yang dibentuk. Berdasarkan arsitektur yang terbentuk, pada penelitian ini dibuat 3 layer konvolusi. Layer konvolusi yang pertama menggunakan ukuran kernel $3 \times 3$ dan map feature 32 dengan max pooling ukuran $2 \times 2$ dengan fungsi aktivasi rule. Layer konvolusi 2 dan 3 menggunakan ukuran kernel 3x3, feature map 64, max pooling 2x2 dan fungsi aktivasi rule. Dalam model ini parameter yang dilatih sebanyak 3,268,611. Terdapat 12544 neuron yang ada di fully connedted layer. Jumlah neuron ini berasal dari citra yang memiliki ukuran 14x14 dengan filter berukuran 64. Fungsi aktivasi yang digunakan adalah sofmax dengan neuron sejumlah 256 dimana outputnya adalah 3 kelas.

Gambar 3 adalah hasil proses pelatihan terhadap data citra insang ikan. Pada penelitian ini nilai epoch yang digunakan adalah 45 . Gambar 4 memperlihatkan grafik pergeseran nilai loss dan akurasi untuk proses training berdasarkan iterasi (epoch). Sedangkan Gambar 5 menunjukan grafik nilai dari validation loss dari data training. Berdasarkan Gambar terlihat bahwa nilai akurasi untuk iterasi awal bernilai rendah. Dari Gambar 4 tersebut nilai akurasi akan semakin meningkat seiring dengan banyaknya iterasi. Sedangkan pada Gambar 5 terlihat bahwa nilai loss bernilai tinggi untuk iterasi awal-awal, sedangkan nilai loss akan semakin menurun seiring dengan banyaknya iterasi yang dilakukan. Berdasarkan model yang sudah dibuat, akurasi tertinggi untuk data training sebesar $100 \%$.

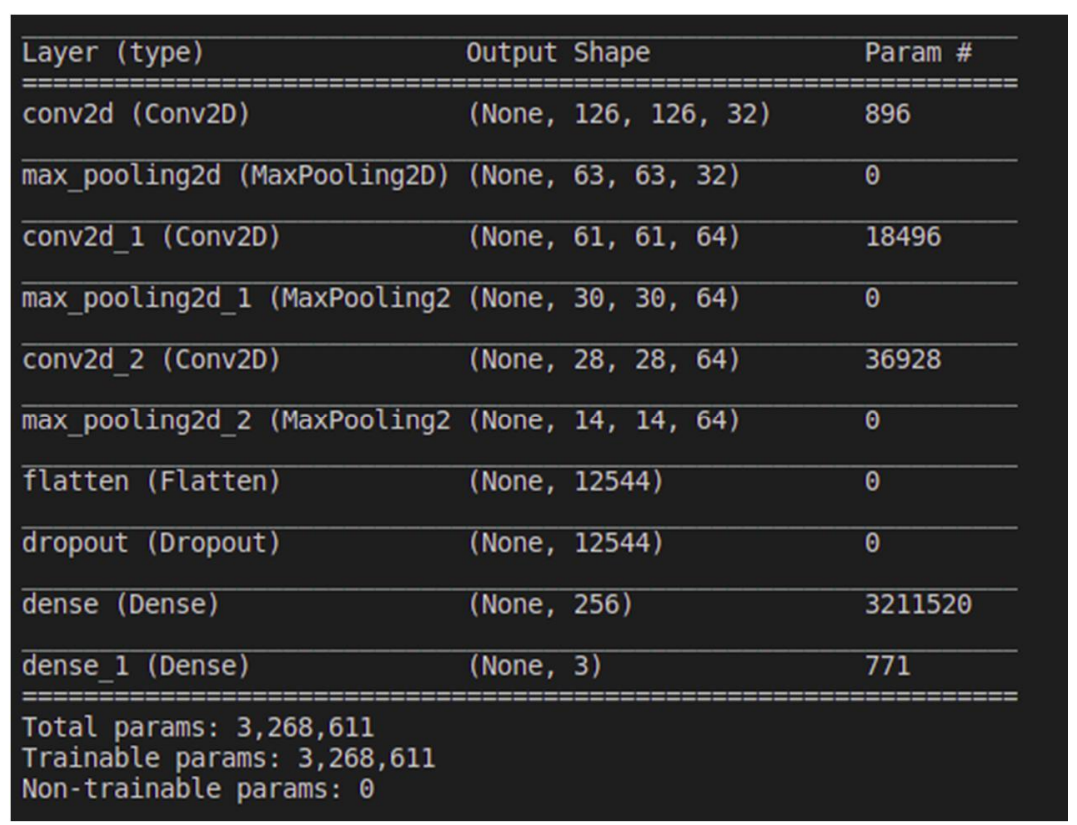

Gambar 2. Arsitektur Jaringan CNN

Miftahus, et., al [Identifikasi Kesegaran Ikan Berdasarkan Citra Insang Dengan Metode Convolution Neural Network] 


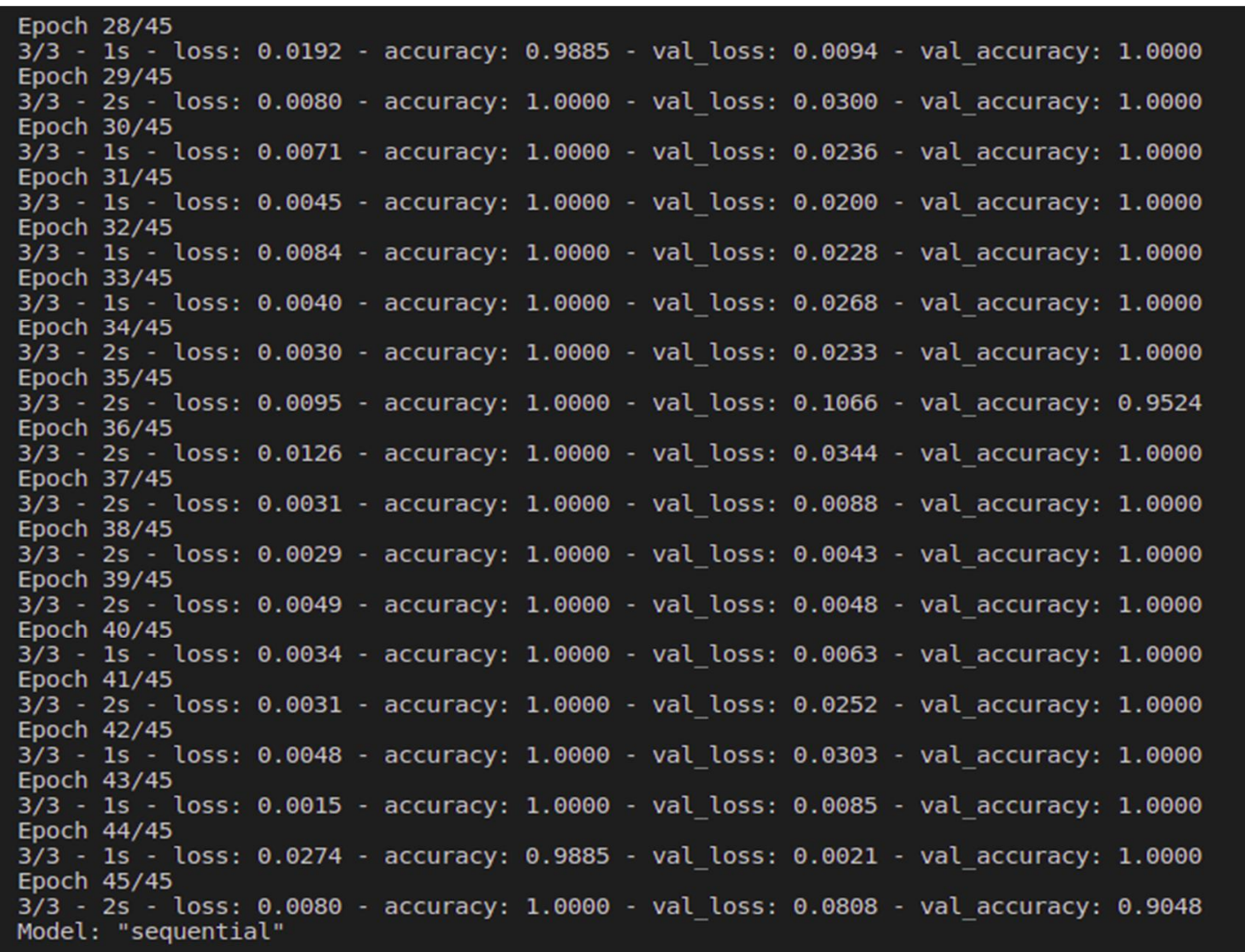

Gambar 3. Pelatihan Data Training

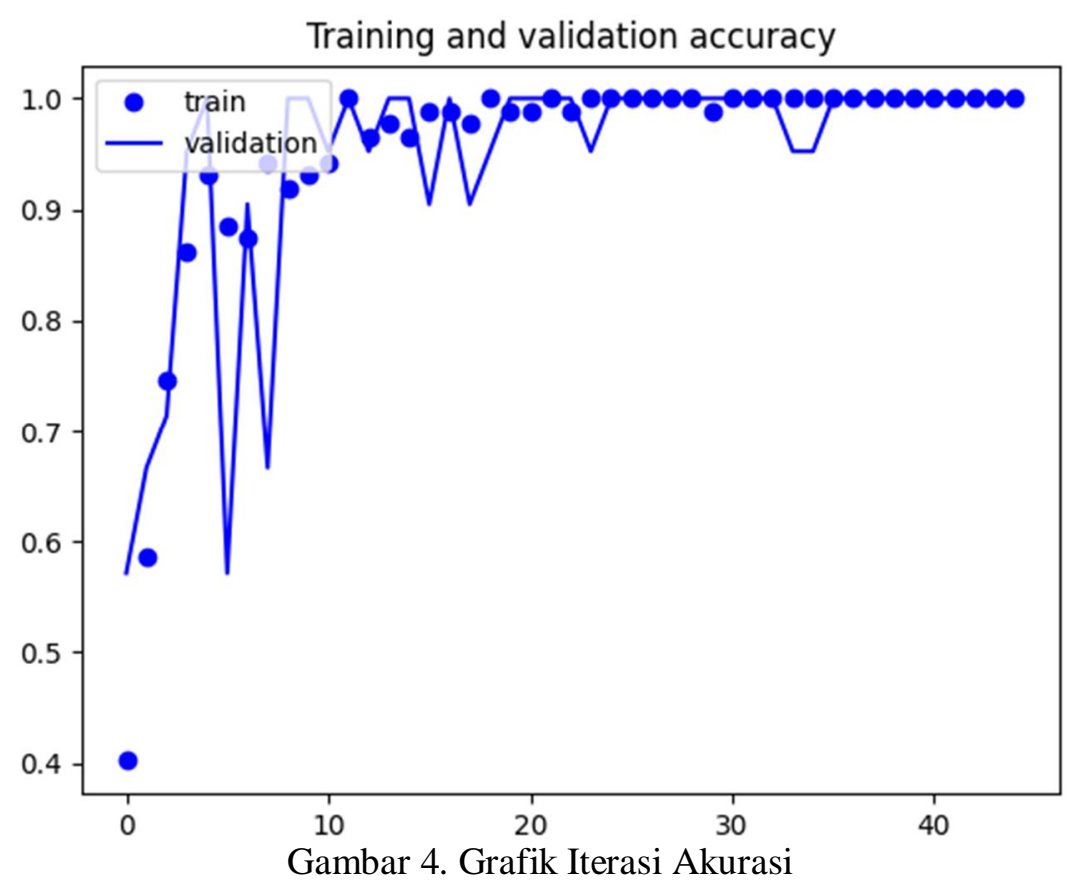

Miftahus, et., al [Identifikasi Kesegaran Ikan Berdasarkan Citra Insang Dengan Metode Convolution Neural Network] 


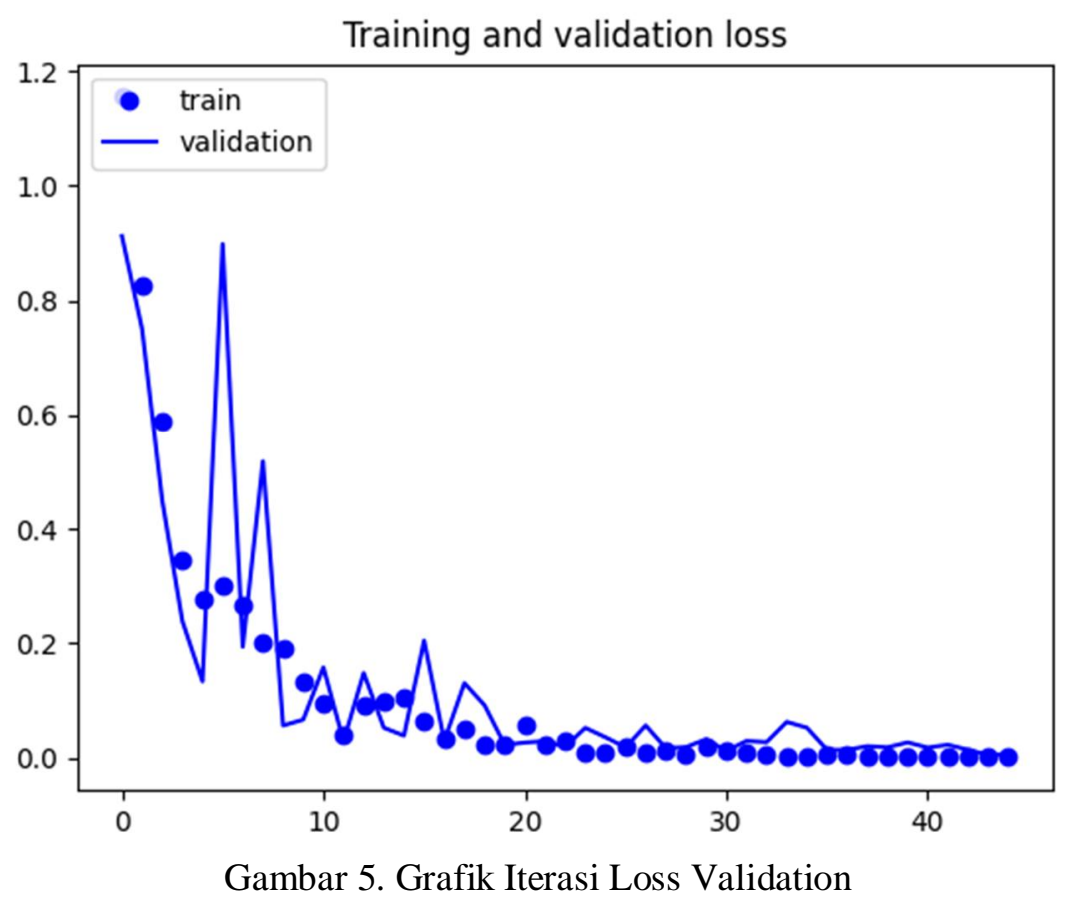

Tabel 1 adalah hasil uji coba terhadap model yang sudah dibuat. Jumlah data uji adalah 45 citra insang ikan tombro yang terdiri dari 15 citra insang ikan tombo segar, 15 insang citra ikan tombro tidak segar, dan 15 insang citra ikan tombro busuk. Berdasarkan Tabel 1 tersebut terdapat satu data citra yang salah dalam proses klasifikasinya. Akurasi yang diperoleh berdasrkan dari data uji adalah sebesar $97,7 \%$.

Tabel 1. Hasil Akurasi dari Data Uji

\begin{tabular}{|c|c|c|c|c|}
\hline No & Label & Benar & Salah & Total \\
\hline 1 & Segar & 15 & 0 & 15 \\
\hline 2 & Tidak Segar & 14 & 1 & 15 \\
\hline 3 & Busuk & 15 & 0 & 15 \\
\hline & Total & 44 & 1 & 45 \\
\hline & Akurasi & \multicolumn{3}{|c|}{$97,7 \%$} \\
\hline
\end{tabular}

\section{KESIMPULAN}

Implementasi CNN untuk klasifikasi kesegaran ikan memberikan nilai akurasi sebesar $100 \%$ untuk proses training, sedangkan untuk proses testing system yang dibangun memberikan akurasi sebesar $97,7 \%$.

\section{SARAN}

Untuk meningkatkan akurasi pada proses testing bisa menambahkan dataset, dismping itu juga bisa dengan menambahkan jumlah layernya. 


\section{UCAPAN TERIMA KASIH}

Penulis mengucapkan banyak terima kasih kepada Universitas Islam Lamongan yang sudah memberikan pendaan terhadap pelaksanaan penelitian ini.

\section{DAFTAR PUSTAKA}

[1] F. M. Diana, "Omega 3 dan Kecerdasan Anak," J. Kesehat. Masy. Andalas, Vol. 7, No. 2, Art. No. 2, Mar. 2013, doi: 10.24893/jkma.v7i2.113.

[2] D. Bee, "Aplikasi Penentuan Tingkat Kesegaran Ikan Selar Berbasis Citra Digital Dengan Metode Kuadrat Terkecil | Bee | d'CARTESIAN." https://ejournal.unsrat.ac.id/index.php/decartesian/article/view/14985 (accessed May 04, 2021).

[3] S. Dwiyatno, I. Iksal, and S. Nugraha, "Alat Pendeteksi Kesegaran Ikan Menggunakan Metode K-Nearest Neighbor Berdasar Warna Mata Berbasis Atmega 328," PROSISKO J. Pengemb. Ris. dan Obs. Sist. Komput., Vol. 5, No. 2, Art. No. 2, Sep. 2018, Accessed: May 2021. [Online]. Available: https://ejurnal.lppmunsera.org/index.php/PROSISKO/article/view/789

[4] I. Indrabayu, M. Niswar, and A. A. Aman, "Sistem Pendeteksi Kesegaran Ikan Bandeng Menggunakan Citra," J. INFOTEL, Vol. 8, No. 2, Art. No. 2, Nov. 2016, doi: 10.20895/infotel.v8i2.119.

[5] N. M. S. Iswari, W. Wella, and R. Ranny, "Perbandingan Algoritma kNN, C4.5, dan Naive Bayes Dalam Pengklasifikasian Kesegaran Ikan Menggunakan Media Foto," Ultim. J. Tek. Inform., vol. 9, no. 2, pp. 114-117, Oct. 2017, doi: 10.31937/ti.v9i2.659.

[6] S. Winiarti, F. I. Indikawati, A. Oktaviana, and H. Yuliansyah, "Consumable Fish Classification Using k-Nearest Neighbor,” IOP Conf. Ser. Mater. Sci. Eng., Vol. 821, p. 012039, May 2020, doi: 10.1088/1757-899X/821/1/012039.

[7] A. Agustyawan, "Pengolahan Citra untuk Membedakan Ikan Segar dan Tidak Segar Menggunakan Convolutional Neural Network," Indones. J. Appl. Inform., Vol. 5, No. 1, Art. no. 1, Nov. 2020, doi: 10.20961/ijai.v5i1.41770.

[8] J. E. Hutagalung, "Identifikasi Kesegaran Ikan Nila Menggunakan Teknik Citra Digital CORE.” https://core.ac.uk/display/333718647?recSetID= (accessed May 08, 2021).

[9] S. Khansa, "Penerapan Ekstraksi Ciri Transformasi Wavelet Dalam Pembuatan Model Klasifikasi Kesegaran Ikan Selar,” Senamika, Vol. 1, No. 2, Art. No. 2, Nov. 2020.

[10] E. Fitriani, "Perbandingan Algoritma C4.5 dan Nä̈ve Bayes Untuk Menentukan Kelayakan Penerima Bantuan Program Keluarga Harapan,” Sist. J. Sist. Inf., Vol. 9, No. 1, Art. No. 1, Jan. 2020, doi: 10.32520/stmsi.v9i1.596.

[11] Ekojono, "Identification of Freshness of Marine Fish Based on Image of Hue Saturation Value and Morphology | Ekojono | Inform: Jurnal Ilmiah Bidang Teknologi Informasi

Miftahus, et., al [Identifikasi Kesegaran Ikan Berdasarkan Citra Insang Dengan Metode Convolution Neural Network] 
dan Komunikasi.” https://ejournal.unitomo.ac.id/index.php/inform/article/view/3228 (accessed May 04, 2021).

[12] W. S. Eka Putra, "Klasifikasi Citra Menggunakan Convolutional Neural Network (CNN) pada Caltech 101," J. Tek. ITS, Vol. 5, No. 1, Mar. 2016, doi: 10.12962/j23373539.v5i1.15696.

[13] T. Shafira, "Implementasi Convolutional Neural Networks Untuk Klasifikasi Citra Tomat Menggunakan Keras," Thesis, Universitas Islam Indonesia, 2018. Accessed: May 04, 2021. [Online]. Available: https://dspace.uii.ac.id/handle/123456789/6345

[14] E. N. Arrofiqoh and H. Harintaka, "Implementasi Metode Convolutional Neural Network Untuk Klasifikasi Tanaman pada Citra Resolusi Tinggi," Geomatika, Vol. 24, No. 2, Art. No. 2, Nov. 2018, doi: 10.24895/JIG.2018.24-2.810.

[15] S. Fauzi, P. Eosina, and G. F. Laxmi, "Implementasi Convolutional Neural Network Untuk Identifikasi Ikan Air Tawar,” Semin. Nas. Teknol. Inf., Vol. 2, pp. 163-167, Oct. 2019.

[16] R. A. Pangestu, B. Rahmat, and F. T. Anggraeny, "Implementasi Algoritma CNN Untuk Klasifikasi Citra Lahan dan Perhitungan Luas," J. Inform. dan Sist. Inf. JIFoSI, Vol. 1, No. 1, Art. No. 1, Mar. 2020.

[17] R. M. Prasmatio, B. Rahmat, and I. Yuniar, "Deteksi dan Pengenalan Ikan Menggunakan Algoritma Convolutional Neural Network," J. Inform. dan Sist. Inf. JIFoSI, Vol. 1, No. 2, Art. No. 2, Jul. 2020.

[18] F. I. Kurniadi, "Klasifikasi Topeng Cirebon Menggunakan Metode Convolutional Neural Network| JATISI (Jurnal Teknik Informatika dan Sistem Informasi)", Accessed: May 04, 2021. [Online]. Available: http://jurnal.mdp.ac.id/index.php/jatisi/article/view/568

[19] M. F. Naufal, "Analisis Perbandingan Algoritma SVM, KNN, dan CNN Untuk Klasifikasi Citra Cuaca," J. Teknol. Inf. Dan Ilmu Komput., Vol. 8, No. 2, Art. No. 2, Mar. 2021, doi: 10.25126/jtiik.2021824553.

[20] A. S. Nurqaderianie, M. Metusalach, and F. Fahrul, "Tingkat Kesegaran Ikan Kembung Lelaki (Rastrelliger Kanagurta) yang Dijual Eceran Keliling di Kota Makassar,” J. IPTEKS Pemanfaat. Sumberd. Perikan., Vol. 3, No. 6, Art. No. 6, Dec. 2017, doi: 10.20956/jipsp.v3i6.3062.

[21] E. Suprayitno, "Kajian Kesegaran Ikan di Pasar Tradisional dan Modern Kota Malang," JFMR J. Fish. Mar. Res., Vol. 4, No. 2, Art. No. 2, Aug. 2020, doi: 10.21776/ub.jfmr.2020.004.02.13.

[22] C. Szegedy et al., "Going Deeper with Convolutions," ArXiv14094842 Cs, Sep. 2014, Accessed: May 10, 2021. [Online]. Available: http://arxiv.org/abs/1409.4842

[23] G. Huang, Z. Liu, L. Van Der Maaten, and K. Q. Weinberger, "Densely Connected Convolutional Networks," in 2017 IEEE Conference on Computer Vision and Pattern Recognition (CVPR), Jul. 2017, pp. 2261-2269. doi: 10.1109/CVPR.2017.243. 
[24] E. Cetinic, T. Lipic, and S. Grgic, "Fine-Tuning Convolutional Neural Networks for Fine Art Classification,” Expert Syst. Appl., Vol. 114, pp. 107-118, Dec. 2018, doi: 10.1016/j.eswa.2018.07.026.

[25] J. Chen, J. Chen, D. Zhang, Y. Sun, and Y. A. Nanehkaran, "Using Deep Transfer Learning For Image-Based Plant Disease Identification,” Comput. Electron. Agric., Vol. 173, p. 105393, Jun. 2020, doi: 10.1016/j.compag.2020.105393.

[26] Y. Lu, S. Yi, N. Zeng, Y. Liu, and Y. Zhang, “Identification of Rice Diseases Using Deep Convolutional Neural Networks,” Neurocomputing, Vol. 267, pp. 378-384, Dec. 2017, doi: 10.1016/j.neucom.2017.06.023.

[27] N. Rahman, "What is The Benefit of Using Average Pooling Rather Than Max Pooling? Quora.” https:/www.quora.com/What-is-the-benefit-of-using-average-pooling-ratherthan-max-pooling (accessed May 10, 2021). 